\title{
Short-term effect of Tramadol injection on the serum levels of Follicle Stimulating Hormone, Luteinizing Hormone and Testos- terone in Male Sahel Goats in Maiduguri, Nigeria
}

\author{
Babagana Bako ${ }^{1}$, Sani Malami ${ }^{2}$, Garba Uthman Sadiq ${ }^{3}$, Lawan Gana Asheikh ${ }^{4}$ \\ ${ }^{1}$ Department of Obstetrics \& Gynaecology. Faculty of Clinical Sciences, University of Maiduguri, Maiduguri. \\ ${ }^{2}$ Department Pharmacology \& Therapeutics, Faculty of Pharmaceutical Sciences, Bayero University, Kano. \\ ${ }^{3}$ Department of Pharmacology \& Toxicology, Faculty of Pharmaceutical sciences, University of Maiduguri, Maiduguri. \\ ${ }^{4}$ Department of Animal Sciences, Faculty of Agriculture, University of Maiduguri, Maiduguri. \\ *Corresponding author E-mail: bgbako@unimaid.edu.ng
}

\begin{abstract}
Tramadol is a synthetic analogue of codeine. Its mood elevation property and sex enhancement potentials are the main reason for its abuse. The aim of the study was to determine the short-term effect of tramadol administration on Follicle Stimulating Hormone (FSH), Luteinizing Hormone (LH) and Testosterone (TEST) levels in Male Sahel Goats. This was an experimental study conducted from 1st October 2017 to 12th November 2017 at the Livestock Teaching and Research Farm, University of Maiduguri, Maiduguri, Borno State Nigeria involving 20 Male Sahel Goats. The goats were divided in to 4 groups of 5 each; group 1 served as control and groups 2, 3 and 4 were injected intramuscularly with $4 \mathrm{mg} / \mathrm{kg}$ (low dose), $8 \mathrm{mg} / \mathrm{kg}$ (medium dose) and $12 \mathrm{mg} / \mathrm{kg}$ (high dose) of Tramadol respectively. The injections were given intramuscularly, 3 times a week for 4 weeks. Blood samples were collected to determine the serum levels of FSH, LH and TEST at 0,1 week, 2 weeks, 3 weeks and 4 weeks of tramadol injections. The Mean \pm SD of the hormones were computed using SPSS 20. The difference in mean was compared using t test and ANOVA with $\mathrm{p}<0.05$ set for statistical significance. The baseline levels of FSH, LH and TEST in Male Sahel Goat in Maiduguri were $2.91 \pm 5.74 \mathrm{Miu} / \mathrm{ml}, 0.29 \pm 0.72 \mathrm{Miu} / \mathrm{ml}$ and $3.92 \pm 6.39 \mathrm{ng} / \mathrm{ml} \mathrm{respectively}$. Only the goats in group 4 showed a significant increase in serum FSH and LH by the 4 th week $(\mathrm{P}=0.01$ and 0.03 respectively) while no significant change was noted in the other groups. The was a decline in the level of Testosterone from 1st week through 4th week in all the experimental group but the level in the control group remain fairly constant throughout the experiment. The decline is inversely proportional to the dose of tramadol injection and most marked in group 4.
\end{abstract}

High dose and prolonged used of Tramadol should be avoided because of side effects of Hypergonadotrophic hypogonadism.

Keywords: FSH; LH, Maiduguri, Sahel goat, Testosterone and Tramadol.

\section{Introduction}

Tramadol (Tramal, TM) is a centrally acting analgesic used for the treatment of moderate to severe pains and its abuse has become a serious problem in many countries, particularly in the Middle East, Africa, and West Asia (Abdel-Hamid et al., 2016). A report in Nigeria by National Drug and Law Enforcement Agency (NDLEA) showed that Kano State has the highest drug abuse rates based on the number of confiscations, arrests of addicts and convictions of arrested dealers (NAFDAC, 2014).

The abuse of Tramadol could be for a variety of reasons but its mood elevation property and sex enhancement potentials are the main reason for its abuse in Northern Nigeria (Ibrahim et al., 2017). Systematic review by Wu et al in 2012 has confirmed the efficacy of Tramadol as a sex enhancing drug but long-term use of opioids including Tramadol have been associated with decreased secretion of GnRH, which in turn leads to reduced levels of Follicle Stimulating Hormone (FSH) and Luteinizing Hormone (LH). This results in decreased testosterone and oestradiol secretion in rats, rabbits and human studies (Ali et al., 2005; Seyfried \& Hester, 2012; Cepeda et al., 2015; ElGaafarawi, 2015; Osadolor \& Omo-Erhabor, 2016;). The resultant hypogonadism will lead to decreased libido and sexual performance. But the short-term effect of 'on-demand' dosing on the gonadotropins and sex hormones has not been clearly defined. Could this sexual enhancement be associated with initial spike of the sex hormones that is followed by gradual fall with continuing use?

Therefore, this research seeks to study whether the on-demand ingestion has any short-term effect on the serum levels of the Follicle Stimulating Hormone, Luteinizing Hormone and Testosterone in Male Sahel Goats.

Long-term use of Tramadol has been associated with a dose dependent reduction in FSH, LH and Testosterone in many studies and these studies used sequential daily dosing of the drug either in humans or animals (Ali et al, 2005; Seyfried \& Hester, 2012; El-Gaafarawi, 2015; Cepeda et al., 2015; Osadolor \& Omo-Erhabor, 2016). The sequential daily dosing is akin to the tramadol use in patients with persistent mild to moderate pain on long-term medication. These researches have firmly established the long-term effect of Tramadol but they did not research or explain the short-term effect of the drug on the sex hormones.

Abuse of Tramadol is quite common because a recent study by Ibrahim et al (2017) showed that 54.4\% of 124 patients attending drug addiction clinic in Maiduguri were abusing tramadol and were initiated via peer influence. These patients can be counselled on the long- 
term consequences but no much information can be given to them regarding the short-term effect of the drug, especially the 'on demand' intake. This is the knowledge gap this study intends to fill.

At the moment there are few studies on the short-term effect of this on-demand use of Tramadol on FSH, LH and TEST in males. Ideally, this study should be conducted in humans but because of the secrecy associated with the abuse of the drug and the difficulty in getting volunteers, this work seeks to replicate the on-demand use of the Tramadol at different dosing rates on male sahel goats and study its short-term effect on FSH, LH and TEST levels. The effect on the gonadotropins and sex hormones may be another way the drug enhances sexual performance. The objective is to determine the short-term effect of on-demand tramadol injection on FSH, LH and Testosterone (TEST) levels in Male Sahel Goats.

\section{Materials and methods}

This experimental study was conducted between $1^{\text {st }}$ October 2017 to $12^{\text {th }}$ November 2017 at the Livestock Teaching and Research Farm, University of Maiduguri, Borno State Nigeria. Maiduguri is located between latitude: $11^{\circ}, 50$ ' 12 ” North and longitude: $13^{\circ} 9$ ' $35^{\prime \prime}$ East and at altitude of $354 \mathrm{~m}(1161 \mathrm{Ft})$ above sea level (DNMA, 2013). Twenty healthy male sahel goats were obtained from the Maiduguri cattle market for the purpose of the study. The goats were allowed free access to water ad-libitum for 2 weeks to acclimatize with their new environment. During this period, they were clinically examined and their wellbeing ascertained by a veterinarian. They were dewormed with stat dose of albendazole tablets at $10 \mathrm{mg} / \mathrm{kg}$ per Os. Intramuscular $20 \%$ oxytetracycline injection at $10 \mathrm{mg} / \mathrm{kg}$ was also given for prophylaxis against protozoan infection. In addition, they were vaccinated with local strain PPR (Capripestovax®). The goats were randomly selected, weighted, neck tagged and assigned in to 4 groups. Weighing was done by balancing the goats in a sac suspended on a spring balance for measurement to the nearest $0.1 \mathrm{~kg}$. The goats had no access to ewe during the study period.

The goats were allocated in to 4 groups, each consisting of 5 goats such that the mean weights of the groups were similar. The experimental grouping was as follows:

Group 1 served as control, Groups 2 (low dose) were given Tramadol at $4 \mathrm{mg} / \mathrm{kg}$, Group 3 (medium dose) were given Tramadol at 8 $\mathrm{mg} / \mathrm{kg}$ and Group 4 (high dose) were given Tramadol at $12 \mathrm{mg} / \mathrm{kg}$.

Groups 2 (low dose) had the minimal effective dose (MED) of the drug at $4 \mathrm{mg} / \mathrm{kg}$ as recommended by de Sousa et al (2008). The dose of $4 \mathrm{mg} / \mathrm{kg}$ is the minimal dose of the tramadol required for adequate analgesia in goats (de Sousa et al., 2008). This translated to $50 \mathrm{mg}$ of the drug in human (which is the minimum dose for analgesia in humans). Group 3 (medium dose) had $8 \mathrm{mg} / \mathrm{kg}$ ( 2 times the recommended analgesic dose) which translated to $100 \mathrm{mg}$ in humans (equivalent to 2 capsules of 50mg each). Group 4 (high dose) had 12 $\mathrm{mg} / \mathrm{kg}$ (3 times the recommended analgesic dose) which translated to $150 \mathrm{mg}$ in humans (equivalent to 3 capsules of $50 \mathrm{mg}$ each). the Tramadol injections were administered intramuscularly.

Tramadol (tramadol $\mathrm{HCl}$ ), $50 \mathrm{mg} / \mathrm{ml}$ injection, manufactured by El-Kahera-pharmaceutical Co., India was obtained from pharmaceutical shop. Its chemical name is $( \pm)$ cis-2-[(dimethylamino) methyl]-1-(3-m ethoxy phenyl) cyclohexanol hydrochloride. Specimen were collected by jugular venipuncture into sterile plain bottles using a $5 \mathrm{ml}$ hypodermic syringe, fitted with 21 gauge needle before the first injection of Tramadol. All the goats were bled to obtain the baseline at 0 hours, then the experimental groups were injected immediately. Thereafter, the goats were bled every week for 4 weeks. For this experiment $5 \mathrm{ml}$ of blood was collected at each bleeding.

Blood samples were allowed to clot at room temperature, immediately transported to the laboratory and stored at $4^{\circ} \mathrm{C}$ before processing within 24 hours of collection. Thereafter, serum samples were separated by centrifugation at 2500 rpm for 15 minutes, placed in appropriately labeled serum vials and stored at $-20^{\circ} \mathrm{C}$ until the end of the experiment. All samples were analyzed at the end of the experiment. FSH and LH concentrations were measured by a double-antibody radioimmunoassay, as described for ovine gonadotropins (Lee et al., 1976; Salamonsen et al., 1973). Testosterone was measured in serum using competitive immune-enzymatic colorimetric method for quantitative determination of Testosterone (TEST). The method was based on the principle of solid phase enzyme-linked immunosorbent assay (ELISA). Accu-bind® (Monobind- Lake Forest, CA 92630 USA) ELISA kits was used according to the manufacturer's specifications with the sensitivity of $0.05 \mathrm{ng} / \mathrm{ml}$.

The goats were identified using a neck tag. The weight and laboratory results of the FSH, LH and TEST of each goat were entered in to a profoma designed for the study.

Data of the study was statistically analyzed using the computer program SPSS 20 (Chicago, IL, USA). The mean concentrations of FSH, LH and TEST before and after the injection were compared using student - $t$ - test and difference between groups compared using ANOVA test. $P$ value of $<0.05$ was considered to be statistically significant.

All experimental procedures were in accordance with the University of Maiduguri Animal Ethics Committee guidelines and Practice for the Care and Use of Animals for Scientific Purposes.

\section{Results}

\subsection{Demographic Characteristics of the goats studied}

The Mean \pm SD weight of the goats was $15.7 \pm 2.4 \mathrm{~kg}$ with the range of $13.0-18.1 \mathrm{~kg}$. There was no statistically significant difference in the Mean \pm SD of the weights in the 4 groups $(F=0.08, P=0.97)$ as shown in Table $\mathrm{I}$.

Table 1: Demographic Characteristics of the Male Sahel Goats

\begin{tabular}{|c|c|c|c|c|}
\hline & Group 1 & Group 2 & Group 3 & Group 4 \\
\hline Tag No & 101 & 201 & 301 & 401 \\
\hline Weight (Kg) & 18.2 & 18.0 & 15.3 & 16.0 \\
\hline Tag No & 102 & 202 & 302 & 402 \\
\hline Weight (Kg) & 16.3 & 16.8 & 14.8 & 17.0 \\
\hline Tag No & 103 & 203 & 303 & 403 \\
\hline Weight $(\mathrm{Kg})$ & 16.2 & 16.8 & 17.4 & 15.4 \\
\hline Tag No & 104 & 204 & 304 & 404 \\
\hline Weight (Kg) & 13.2 & 14.0 & 16.0 & 14.0 \\
\hline Tag No & 105 & 205 & 305 & 405 \\
\hline Weight (Kg) & 14.0 & 14.0 & 15.7 & 15.5 \\
\hline Mean \pm SD $(k g)$ & $16.1 \pm 1.7$ & $15.7 \pm 2.1$ & $15.8 \pm 2.1$ & $15.6 \pm 1.5$ \\
\hline
\end{tabular}




\subsection{Baseline serum levels of FSH, LH and test in male sahel goats in Maiduguri}

The baseline levels (Mean \pm SD) of FSH, LH and TEST testosterone in Male Sahel Goat in Maiduguri were 2.91 $\pm 5.74 \mathrm{Miu} / \mathrm{ml}$, $0.29 \pm 0.72 \mathrm{Miu} / \mathrm{ml}$ and $3.92 \pm 6.39 \mathrm{ng} / \mathrm{ml}$ respectively as shown in Table II.

Table 2: Baseline Serum Levels of FSH, LH and TEST in Male Sahel Goat in Maiduguri

\begin{tabular}{llll}
\multicolumn{1}{c}{ Table 2: Baseline Serum Levels of FSH, LH and TEST in Male Sahel Goat in Maiduguri } & Mean \pm SD & Range \\
\hline 1 & Hormone & $2.91 \pm 5.74 \mathrm{Miu} / \mathrm{ml}$ & $0.1-13.2 \mathrm{Miu} / \mathrm{ml}$ \\
2 & Follicle Stimulating Hormone (FSH) & $0.29 \pm 0.72 \mathrm{Miu} / \mathrm{ml}$ & $0.1-1.7 \mathrm{Miu} / \mathrm{ml}$ \\
3 & Testosterone (TEST) & $3.92 \pm 6.39 \mathrm{ng} / \mathrm{ml}$ & $0.1-14.0 \mathrm{ng} / \mathrm{ml}$ \\
\hline
\end{tabular}

\subsection{Change in the FSH levels with increasing dose Tramadol injection in male sahel goats}

The baseline FSH of the 3 experiment groups were similar $(\mathrm{F}=0.08, \mathrm{P}=0.99)$. After the first Tramadol injection, the FSH showed a gradual rise but the differences in the groups was not statistically significant. From the $1^{\text {st }}$ week through the $4^{\text {th }}$ week there was markedly higher rise in the FSH in group $4(12 \mathrm{mg} / \mathrm{kg})$ compared to groups 2 and 3 but the value did not differ significantly from that of the control group. This is also shown in figure 1.

\subsection{Change in the LH level with increasing dose of tramadol in male sahel goats}

As shown in Figure 2, the effect of the increasing dose of tramadol injections on the level of LH is more pronounced in the high dose (12 $\mathrm{mg} / \mathrm{kg}$ ) group and it became statistically significant by the $4^{\text {th }}$ week. By the $4^{\text {th }}$ week, the mean LH for the groups 1 , 2 , 3 and 4 were $0.25 \pm 0.12,1.27 \pm 1.86 \mathrm{Miu} / \mathrm{ml}, 0.26 \pm 0.05 \mathrm{Miu} / \mathrm{ml}$ and $3.55 \pm 2.31 \mathrm{Miu} / \mathrm{ml}$ respectively with $\mathrm{F}=4.84$ and $\mathrm{P}=0.01$.

\subsection{Change in the level of TEST with increasing dose of Tramadol injection in male sahel goats.}

The was a decline in the level of Testosterone from $1^{\text {st }}$ week through $4^{\text {th }}$ week in all the experimental group but the level in the control group remain fairly constant throughout the experiment. The decline is inversely proportional to the dose of tramadol injection from $1^{\text {st }}$ week till the end of the study as shown in Figure 3. Analysis of variance showed that the fall in TEST was consistent and the lowest value was obtained at the $4^{\text {th }}$ week and this was tending toward statistical significance with $\mathrm{P}=0.06$.

\subsection{Other findings}

1) All the goats in the treatment group lost weight, Mean \pm SD of $15.75 \pm 0.08 \mathrm{~kg}$ VS $13.44 \pm 0.92 \mathrm{~kg}$ with $\mathrm{t}=4.60$ and $\mathrm{P}=0.04$. The loss of weight was more in the $8 \mathrm{mg} / \mathrm{kg}$ and the $12 \mathrm{mg} / \mathrm{kg}$ groups. There was also a decline in the quantity of food consumed by the group after the first week of injection.

2) One of the high dose goats (Tagged 403) convulsed after the first injection. The goat was resuscitated and continued the experiment without any problem. Subsequent injections were tolerated well.

3) One of the goats in the control group (Tagged 104) died after a week of commencement of the experiment. Autopsy was done and finding suggested Pneumonia as the likely cause of death.

$$
\text { Control }=\operatorname{Low}(4 \mathrm{mg} / \mathrm{kg})=\operatorname{Medium}(8 \mathrm{mg} / \mathrm{kg})=\mathrm{High}(12 \mathrm{mg} / \mathrm{kg})
$$

$\mathrm{FSH}(\mathrm{Miu} / \mathrm{ml})$

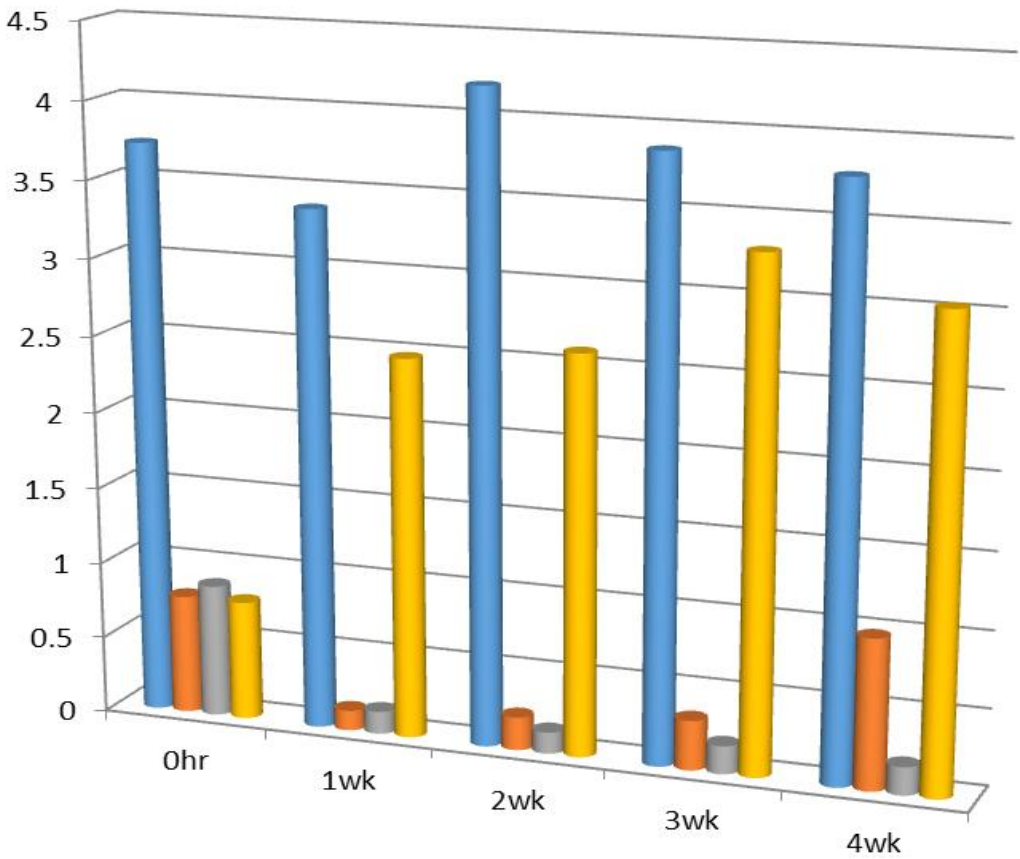

Fig. 1: Effect of the Different Doses of Tramadol Injection on FSH Levels in Male Sahel Goats. 
Control $\square$ Low(4mg/kg) $\square$ Medium(8mg/kg) $\square$ High(12mg/kg)

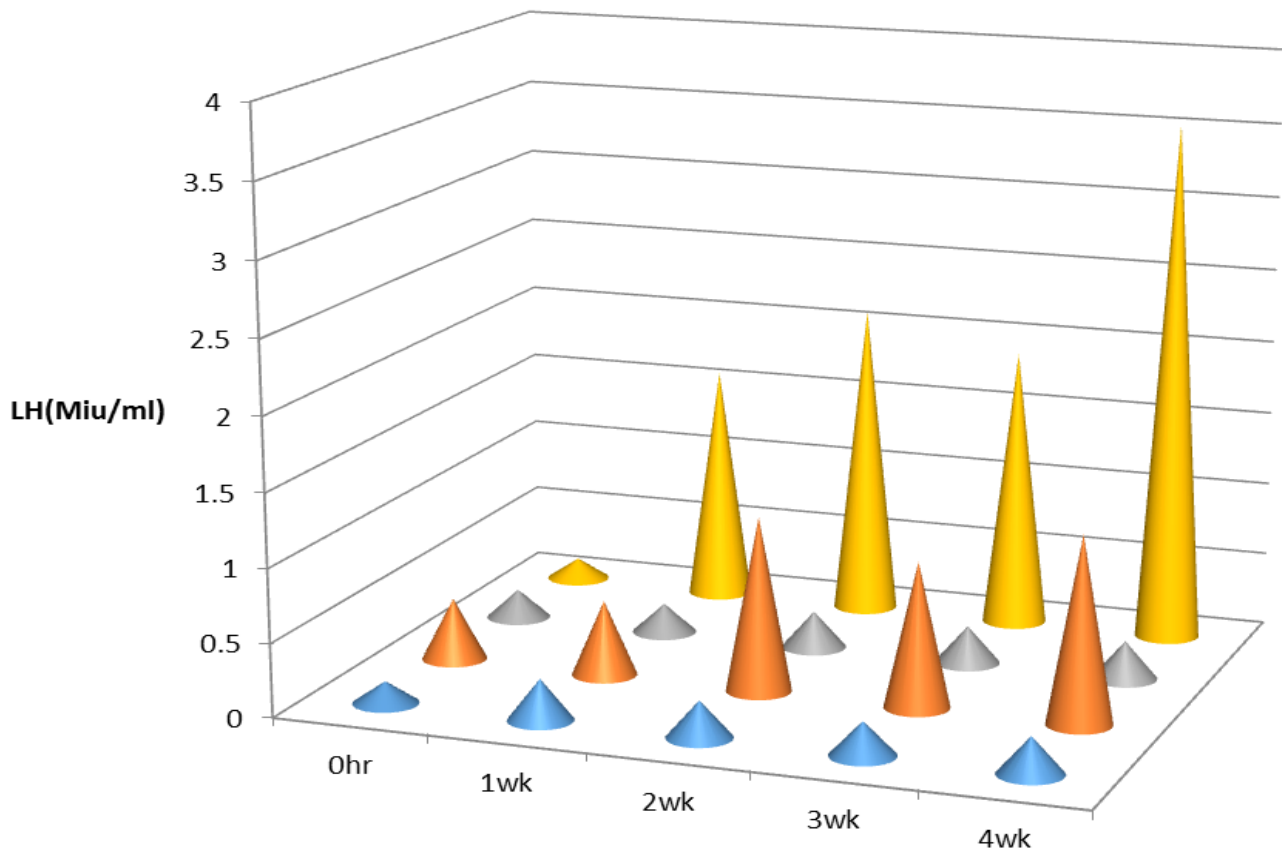

Fig. 2: Effect of Different Doses of Tramadol on LH Levels in Male Sahel Goats.

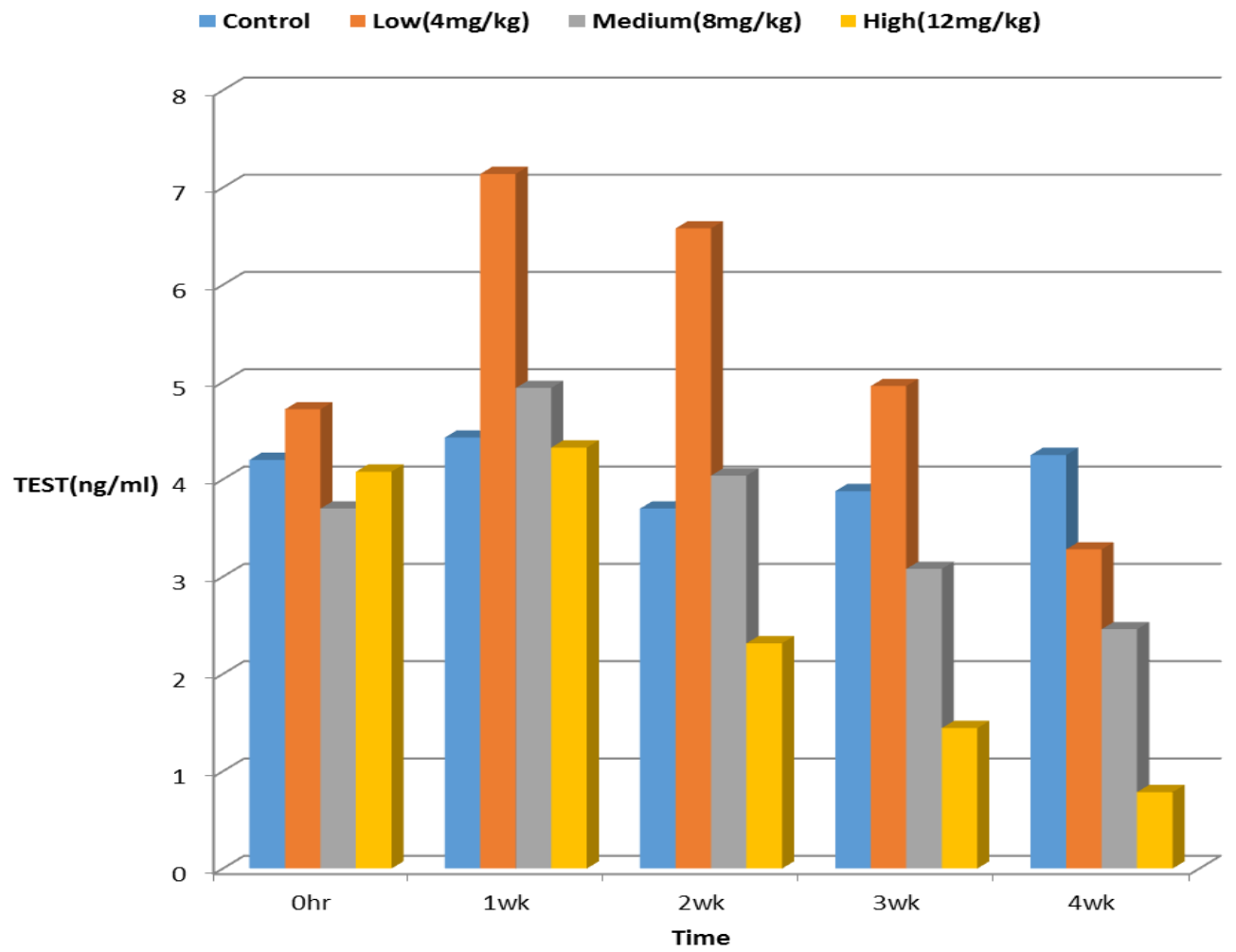

Fig. 3: Effect of Different Doses of Tramadol on TEST Levels in Male Sahel Goats.

\section{Discussion}

The baseline FSH of $2.91 \pm 5.74 \mathrm{Miu} / \mathrm{ml}$ observed in this study is lower than $11.7 \pm 6.26 \mathrm{Miu} / \mathrm{ml}$ reported by Oloye et al (2017) amongst West African Dwarf goat in Abeokuta, Nigeria. This may be because of the difference in sample size. While Oloye et al (2017) studied 12 goats, this study collated the FSH in 20 goats over a period of 4 weeks. Seasonal variation might also be another factor as FSH is known to peak among seasonal goat in July (Howland et al., 1985) but the West African male Sahel goats used in this study are not seasonal breeders. A study by Maina, Chaudhari \& Ribadu (2006), on the effect of Ecotype on Semen Characteristics of Sahel Goats in Maiduguri showed no change in the quality of the sperm of these goats over the period of one year. However, Dias et al (2017) reported a lower baseline value of $0.10 \pm 0.04 \mathrm{Miu} / \mathrm{ml}$ in Alpine goats in Brazil in the month of October. The differences in geographical location, seasonal and genetic variation may account for the disparity in FSH in these studies. 
The baseline LH obtained in this study is lower than $2.31 \pm 0.06 \mathrm{Miu} / \mathrm{ml}$ and $31.38 \pm 37.75 \mathrm{Miu} / \mathrm{ml}$ reported in Nsuka (Okpe \& Anya, 2017) and Abeokuta (Oloye et al., 2017) respectively, both studies were conducted in West African dwarf goats in southern, Nigeria. However, the baseline LH obtained in this study agrees with $0.36 \pm 0.17 \mathrm{Miu} / \mathrm{ml}$ found in Alpine goats in Brazil (Dias et al., 2017).

The baseline TEST level in this study $(3.92 \pm 6.39 \mathrm{ng} / \mathrm{ml}$ ) is higher than $1.0 \pm 1.21 \mathrm{ng} / \mathrm{ml}$ (Oloye et al., 2017), $2.83 \pm 0.49 \mathrm{ng} / \mathrm{ml} \mathrm{reported} \mathrm{by}$ Dias et al (2017) and $2.97 \pm 0.03 \mathrm{ng} / \mathrm{ml}$ reported by Okpe \& Anya (2017). The high TEST measured reported in this study may be due to genetic and environmental factors.

Mc Call (2015), reported that, only free Testosterone, unbound by sex-hormone-binding globulin (SHBG), can enter and activate androgen receptors in cells, resulting in testosterone-mediated effects (both physical and sexual). She suggested that free Testosterone should replace total testosterone as better marker of hypogonadism or testosterone deficiency. The free Testosterone kit is not available in our setting and it is very expensive to use.

The levels of the FSH showed a slight fluctuation during the experiment but it remained within the reference range when compared with the values in the control group. These fluctuations were most noticed in the high dose group with the highest level of the FSH seen by the $4^{\text {th }}$ week of the study and that coincided the period of lowest level of TEST in that group. In contrast to the finding in goats, Osadolor and Omo-Erhabor, (2016) observed in their experiment on the Effects of Tramadol on FSH, LH, Prolactin, Testosterone, Estrogen and $\beta$ HCG) in laboratory Rabbits, that tramadol leads to a fall in FSH. But their findings on LH and TEST are similar to the findings of this study. The raised FSH and LH at the end of the study which is also in tandem with the low TEST may be attributed to lack of negative feedback on both pituitary and hypothalamus. This finding contrasts with hypogonadism expected from long term use of opioids as reported by (Seyfried \& Hester, 2012; Cepeda et al, 2015). In addition, the contrast can also be because of the short duration of the study as the long-term usage of opioids may actually be described in months or even years. Cepeda et al (2015), opined that the opioids will suppress the hypothalamus leading to reduced release of GnRH, and adversely affects LH levels, and subsequently TEST synthesis and secretion. Similarly, a hypogonadism associated syndrome of low levels of TEST with resultant reduced libido, fatigue, decreased muscle mass, and osteopenia has been described by Seyfried \& Hester (2012).

The level of LH showed slight elevation over the treatment period and it was most elevated in the high dose group. This finding contrast to the observation made by Oloye et al (2017) using ethanol extract of Spondias mombin in which the level of LH did not show significant fluctuation upon administration of the extracts. Other studies on the Hypothalamus and pituitary by previous workers on Rams and Rhesus Monkey have also shown that LH is affected more by TEST while FSH is controlled by both TEST and Inhibin. (Tilbrook \& Clarke, 2001). The high level of LH at the end of the $4^{\text {th }}$ week in this study also coincided with the time of low level of TEST and that may mean lack of negative feedback of TEST on the pituitary as asserted by the above study.

The finding of this study showed a gradual decline of the level of TEST over the period of tramadol usage, suggest another explanation to the possible mechanism of action of the tramadol as a sex enhancing drugs. This may be because of dampening of excitement with continuing use of a steady dose of the Tramadol and this is direct opposite what is expected of a sex enhancing drug which is otherwise expecting to increase the sexual drive. It is possible that the mechanism of action of Tramadol may be due its antidepressant effect rather than change in sex hormones levels. Even though a study in a strip club showed rising levels of TEST among men in anticipation of sex or excitement, that rise may be transient and can be missed by this study which determined the hormone change at weekly intervals. A shorter duration of bleeding may be required to detect swift changes of the sex hormones to drugs particularly that the peak of Tramadol action is 2 hours (Grond \& Sablotzki, 2004). Tramadol has antidepressant activity as a Selective Serotonin Re-uptake Inhibitors (SSRI) which increases the levels of serotonin and norepinephrine in the brain (Safarinejad \& Hosseini, 2006).

The low dose appears to be safe especially in short term as no significant suppression of the hormones was noted at the end of the study. However, more studies may be needed to elucidate this claim. While, the decline in TEST levels and the rise in FSH and LH in the high dose is tending towards hypergonadotropic hypogonadism and its untoward effects, hence the need to avoid the high dose of Tramadol. Besides the FSH, LH and TEST studied in the goat, other observation such as weight loss and reduced feeding were also noted. These were more pronounced in the $12 \mathrm{mg} / \mathrm{kg}$ and can advsersely affect meat production and is counter productive to the animal breeders. The anorexia may be attributed to the excitement associated with the tramadol but effects on the body metabolism cannot be ruled out.This finding further butresses the safety concerns with the use of the high dose and hence, it is discouraged.

\section{Conclusion}

The baseline levels (Mean \pm SD) of FSH, LH and TEST in Male Sahel Goat in Maiduguri are 2.91 $\pm 5.74 \mathrm{Miu} / \mathrm{ml}, 0.29 \pm 0.72 \mathrm{Miu} / \mathrm{ml}$ and $3.92 \pm 6.39 \mathrm{ng} / \mathrm{ml}$ respectively. There is a significant change in the levels of FSH, LH and TEST following Tramadol injection especially at higher doses $(12 \mathrm{mg} / \mathrm{kg})$.

We recommend that Tramadol at low dose $(4 \mathrm{mg} / \mathrm{kg})$ can be used to enhance sexual activity in seasonal goats for better animal production. More research should be done to ascertain the safe levels of the drug, its effect on the testicles and sperm production, liver and kidneys.

\section{Limitations of the study}

The small sample size particularly the number of goats in each of the experimental group and this was due to the cost of keeping the animals. Secondly, the interval bleeding may be too long as circadian rhythm was not observed. Thirdly, no clinical observation of other sexual behavior was done as the increase in TEST could have manifested clinically as aggression and increased libido. Lastly, the goat should have been followed up after the study to check for recovery and subsequent change in the levels of the hormones.

\section{References}

[1] Abdel-Hamid, I. A., Andersson, K., Waldinger, M. D., \& Anis, T. H. (2016). Tramadol Abuse and Sexual Function. Sexual Medicine Reviews, 4(3), 235-246. https://doi.org/10.1016/j.sxmr.2015.10.014.

[2] Ali, O.K., Ahmed, A.S., \& Mawlood, A. (2005). Effects of Tramadol on Histopathological and Biochemical. Parameters in Male Rabbits. American Journal of Biology and Life Sciences, 3(3), 85-90.

[3] Cepeda, M.S., Zhu, V., Vorsanger, G., \& Eichenbaum, G. (2015). Effect of Opioids on Testosterone Levels: Cross-Sectional Study using NHANES. Pain Medicine, 16, 2235-2242. https://doi.org/10.1111/pme.12843. 
[4] De Sousa, A.B., Santos, A.C., Schramm, S.G., Porta, V., Górniak, S.L., Florio, J.C., \& de Souza Spinosa, H. (2008). Pharmacokinetics of tramadol and O-desmethyltramadol in goats after intravenous and oral administration. Journal of Veterinary Pharmacology and Therapeutics, 31, 45-51.

[5] Dias, J.C.O., Veloso, C.M., da Rocha Santos, M.C., de Oliveira, C. T. S.A., Silveira, C.O., Iglesias, E., Maitan, P.P., \& Sanglard, L.M.P. (2017). Seasonal variation in the reproductive activity of male goats raised under tropical climate conditions. Brazilian Journal of Animal Science, 46(3), 192-201. https://doi.org/10.1590/s1806-92902017000300003.

[6] DNMA (2013, Nov 8). Data reported by the weather station, 652015. Department of Nigerian

[7] Metrological Authority (DNMA). Retrieved from www.dnma.org.

[8] El-Gaafarawi, I. I. (2015). Biochemical Toxicity Induced By Tramadol Administration in Male Rats. Egyptian Journal of Hospital Medicine, 23, $353-362$.

[9] Grond, S., \& Sablotzki, A. (2004). Clinical pharmacology of tramadol. Clinical Pharmacokinetics, 43(13), 879-923. https://doi.org/10.2165/00003088-200443130-00004.

[10] Howland, B.E., Sanford, L.M., \& Palmer, W.M. (1985). Changes in Serum Levels of LH, FSH, Prolactin, Testosterone, and Cortisol Associated with Season and Mating in Male Pygmy Goats. Journal of Andrology, 6, 89-96. https://doi.org/10.1002/j.1939-4640.1985.tb00822.x.

[11] Ibrahim, A. W., Yerima, M. M., Pindar, S. K., Onyencho, V. C., Ahmed, H. K., Machina, B. K., Shehu, S., Rabbebe, I. B., \& Wakil, M. A. (2017). Tramadol Abuse among Patients Attending an Addiction Clinic in North-Eastern Nigeria: Outcome of a Four-Year Retrospective Study. Advances in Psychology and Neuroscience, 2(2-1), 31-37. doi: 10.11648/j.apn.s.2017020201.16

[12] Lee, V.W., Cumming, I.A., de Kretser, D.M., Findlay, J.K., Hudson, B., \& Keogh, E.J. (1976). Regulation of gonadotrophin secretion in rams from birth to sexual maturity. I. Plasma LH, FSH and testosterone levels. Journal of Reproduction and Fertility, 46, 1-6. https://doi.org/10.1530/jrf.0.0460007.

[13] Maina, V. A., Chaudhari, S.U.R., \& Ribadu, A.Y. (2006). Effect of Ecotype on Semen Characteristics of Sahel Goats in Borno State. Journal of Applied Sciences, 6, 1220-1224. https://doi.org/10.3923/jas.2006.1220.1224.

[14] Mc Call, B. (2015). Testosterone May Help Diagnose Hypogonadism-Medscape. (Retrieved from https://www.medscape.com/viewarticle/844903\#vp_1)

[15] Mc Mahon, C.G. (2016). Emerging and investigational drugs for premature ejaculation. Translational Andrology and Urology, 5(4), 487-501. https://doi.org/10.21037/tau.2016.04.02.

[16] NAFDAC (2014). Drug use on the rise in Nigeria's biggest city. (n.d.). Retrieved, from http://m.news24.com/news24/Africa/News/Drug-use-onthe-rise-in-Nigerias-biggest- city-20140107.

[17] Okpe, G.C., \& Anya, K.O. (2017). Evaluation of Testis Biometry, Sperm and Hormone Profiles of Naturally Unilateral Cryptorchid West African Dwarf Goats. Annals of Reproductive Medicine and Treatment, 2(1), 1007.

[18] Oloye1, A.A., Ola-Davies, O.E., \& Oyeyemi, M.O. (2017). Haemogram and hormonal profile of WAD bucks treated with leaf ethanolic extract of Spondias mombin. Sokoto Journal of Veterinary Sciences, 15(3), 85 - 90. https://doi.org/10.4314/sokjvs.v15i3.12.

[19] Osadolor, H.B., \& Omo-Erhabor, J.A. (2016). Effects of Tramadol on Fertility Hormones (Follicle Stimulating Hormone, Leutinizing Hormone, Prolactin, Testosterone, Estrogen and $\beta-\mathrm{HCG})$ in Laboratory Rabbits. British Journal of Medicine \& Medical Research, 14(8), 1- 11. https://doi.org/10.9734/BJMMR/2016/24620.

[20] Salem, E.A., Wilson, S.K., Bissada, N.K., Delk, J.R., Hellstrom, W.J., \& Cleves, M.A. (2008). Tramadol HCL has promise in on-demand use to treat premature ejaculation. The Journal of Sexual Medicine, 5(1), 188-193. https://doi.org/10.1111/j.1743-6109.2006.00424.x.

[21] Safarinejad, M. R., \& Hosseini, S. Y. (2006). Safety and Efficacy of Tramadol in the Treatment of Premature Ejaculation. Journal of Clinical Psychopharmacology, 26(1), 27-31. https://doi.org/10.1097/01.jcp.0000195110.79027.3f.

[22] Salamonsen, L.A., Jonas, H.A., Burger, H.G., Buckmaster, J.M., Chamley, W.A., \& Cumming, I.A. (1973). A heterologous radioimmunoassay for follicle stimulating hormone: application to measurement of FSH in the ovine estrous cycle, and in several other species including man. Endocrinology, 93, 610-618. https://doi.org/10.1210/endo-93-3-610.

[23] Seyfried, O., \& Hester, J. (2012). Opioids and endocrine dysfunction. British Journal of Pain 201, 6(1), 17-24. https://doi.org/10.1177/2049463712438299.

[24] Souza, M.J., \& Cox, S.K. (2011). "Tramadol use in zoologic medicine". Veterinary Clinics of North America: Small Animal Practice, 14 (1), 117130. https://doi.org/10.1016/j.cvex.2010.09.005.

[25] Tilbrook, AJ. \& Clarke, I.J. (2001). Negative Feedback Regulation of the Secretion and Actions of Gonadotropin-Releasing Hormone in Males, Biology of Reproduction, 64(3), 735-742. https://doi.org/10.1095/biolreprod64.3.735.

[26] Tsutsumi, R. \& Webster, N.J.G (2009). GnRH Pulsatility, the Pituitary Response and Reproductive Dysfunction. Endocrine Journal, 56(6), 729737. https://doi.org/10.1507/endocrj.K09E-185.

[27] Weatherbase (2013, Nov 11). Maiduguri, Nigeria -Travel and Vacation Weather Averages and

[28] Current Conditions. Eight Years Maiduguri weather report. Retrived from www.tutiempo.net.

[29] Wu, T., Yue, X., Duan, X., Luo, D., Cheng, Y., Tian, Y., \& Wang, K. (2012). Efficacy and Safety of Tramadol for Premature Ejaculation: A Systematic Review and Meta-analysis. Andrology, 3(80), 618-624. https://doi.org/10.1016/j.urology.2012.05.035. 